\title{
NUMERICAL MODELING OF MUD VOLCANOES AND THEIR FLOWS USING CONSTRAINTS FROM THE GULF OF CADIZ
}

\author{
Bramley Murton and Juliet Biggs* \\ Southampton Oceanography Centre, Empress Dock, Southampton, SO14 3ZH, England \\ E_mail: bjm@soc.soton.ac.uk \\ *Currently at: Dept. of Earth Sciences, University of Cambridge, Downing Street, Cambridge, CB2 \\ 3EA, England.
}

\begin{abstract}
Mud volcanoes, ranging in size between $50 \mathrm{~cm}$ and $800 \mathrm{~m}$ high, are found both on land and in submarine environments. Their variation in height and shape reflects the driving forces building them and the physical properties of their materials. The driving force behind the construction of mud volcanoes is overpressure of fluidised mud at depth within the sediment column. Although some component of overpressure may derive from volatile generation in a mud reservoir by dehydration of clay minerals and regional tectonic compressive stresses, a major parameter is the thickness of the sediment column. The maximum height theoretically attained by mud volcanoes is, therefore, largely a function of the density contrast between the fluidised mud and its sedimentary overburden, and the depth of the mud source. From a model of isostatic compensation between the mud column and the sediment column, we are able to predict the depth of fluidised mud reservoirs beneath mud volcanoes. Once erupted, the general behaviour of mud flows is also predictable. Using a viscous-gravity current model to describe the eruption of individual mud flows, we argue that conical-shaped mud volcanoes comprise multiple, superimposed radial flows. The model demonstrates that the thickness, eruption rate and speed of mud flows is strongly dependant on the viscosity, density and over-pressure of the fluidised mud. Assuming continuity in these parameters, the model predicts the lowermost flows will be the oldest, thickest and have the greatest length while the uppermost flows will be the youngest and thinnest and shortest. This model is in contrast to more traditional models of stratiform mud volcano construction in which younger flows progressively bury older ones and travel furthest from the summit.
\end{abstract}


Our model predictions are tested against observations of submarine mud volcanoes in the Gulf of Cadiz and the Moroccan Margin. The surface morphology of two prominent circular mud volcanoes, their bathymetric profiles and evidence from gravity cores taken from their summits are consistent with the volcanoes having reached their maximum height, and being formed from a series of superimposed radial flows in which the outer ones are oldest. Applying our model to the two studied mud volcanoes, we derive quantitative estimates of flow rates, exit and flow velocities, eruption durations, heights and conduit radii. For example, with an average kinematic viscosity of $1.5 \mathrm{~m}^{2} \mathrm{~s}^{-1}$ for the fluidised mud breccia, a density of $1.8 \mathrm{~g} / \mathrm{cc}$, and individual flow heights of between $1.3 \mathrm{~m}$ and $1.6 \mathrm{~m}$, we calculate eruption rates of between 10 and $20 \mathrm{~m}^{3} \mathrm{~s}^{-1}$. At these rates, the mud flows require between 5 and $12 \mathrm{hrs}$ to reach the flanks of the volcanoes. For a flow rate of $10 \mathrm{~m}^{3} \mathrm{~s}^{-1}$, the volcano has an average conduit radius of $1.4 \mathrm{~m}$, giving an exit velocity for the fluidised mud breccia of about $1.6 \mathrm{~ms}^{-1}$. Also, using our model of isostatic compensation, we predict the depth of the mud reservoir to be about $4600 \mathrm{~m}$. To construct conical-shaped mud volcanoes of $\sim 250 \mathrm{~m}$ height, like the two studied in the Gulf of Cadiz, we estimate a total of $\sim 234$ flows taking a minimum of 117 days of eruption activity.

\section{9 words}

\section{Key words: Mud volcanoes, numerical modelling, Gulf of Cadiz}

\section{Introduction}

Submarine mud volcanoes, ranging in size between $50 \mathrm{~cm}$ and $800 \mathrm{~m}$ high occur world-wide on continental shelves, slopes and in the abyssal parts of inland seas. It is estimated that total number of submarine mud volcanoes is between one thousand and one hundred thousand (Milkov, 2000). Two major processes are identified as forming mud volcanoes: high sedimentation rates and lateral tectonic compression, both causing over-pressure of a fluidised mud source at depth within the sediment column. Within these processes, two basic mechanisms are further thought to account for the actual eruption of fluidised mud on the sea floor: the unroofing and exposure of upward migrating shale diapirs, and the rise of fluidised sediments along crustal pathways that typically include fault planes. In both cases, fluid subsurface migration is considered critical to the formation of mud volcanoes (Milkov, 2000). 
Some studies (e.g. from the Barbados accretionary complex) have linked the morphology of submarine mud volcanoes to different development stages and processes of mud fluidisation (Limonov et al., 1997; Lance et al., 1998). Conical-shaped mud volcanoes ("mud-mounds" or gryphons), that do not have any central summit "mud lakes" (or salses), are formed by the expulsion of plastic mud in concentric radial flows. In contrast, shearing within the feeder conduit liquifies the mud leading to the formation of flat-top mud volcanoes ("mud-pies") with central "mud lakes" and elongated, radial mud-flow tongues. In both types, the mud is found to have plastic fluid behaviour in which the plastic threshold decreases with porosity. Thixotropy is associated with high porosity (e.g. more than 70\%), which is often related to the dissociation of gas hydrate (Lance et al., 1998).

Often mud volcanoes are associated with methane fluxes, either as free gas or, depending on ambient temperature and pressure conditions, as gas hydrate (Limonov et al., 1997; Cronin et al., 1997). On this basis, Hovland et al. (1997) argue that the global flux of methane to the atmosphere from the world's terrestrial and submarine mud volcanoes is "highly significant".

The relative difficulty in studying submarine mud volcanoes, compared with their terrestrial counterparts, leaves substantial gaps in our knowledge about modes of formation, the duration and frequency of eruptions and the fluxes of mud and volatiles from the subsurface. Here, we attempt to introduce a simplified, numerical model for the formation of conical-shaped mud volcanoes. Our model is based on data for mud volcanoes in the Gulf of Cadiz, collected during cruises TTR-9 and TTR-10 of the RV Professor Logachev. The model yields estimates for eruption rate and duration of the two individual mud volcanoes. Although we base our model on what are described as the "conical" types of mud volcano, it is useful as a way of identifying the first order paramaters that control mud volcano formation in general and as a way of estimating the fluxes of fluids from the subsurface.

\section{Data}


The data used here are from a study of the Gulf of Cadiz, made during cruises TTR-9 and TTR10 of the R/V Professor Logachev (figure 1) and reported primarily by Gardner (2000) in Kenyon et al., (2000).

\subsection{Geological Setting}

Interaction between the Iberian and African plates have resulted in a complex sedimentary and tectonic history for the Gulf of Cadiz and adjacent continental margins, in the eastern North Atlantic. This history includes several episodes of extension and compresion since the Triassic (Wilson et al., 1989, Dewey et al., 1989; Srivasta et al., 1990; and Maldonado et al., 1999). During the Late Tortonian, westward movement of the Gibralta Arc caused the Gulf of Cadiz to form a forearc basin (Maldonado and Comas, 1992). As a result, olistrome emplacement occurred forming accretionary wedge-type clastic deposition and later deformation (Blankenship, 1992; Flynch et al., 1996; Maldonado and Somoza, 1997; Maldonado et al., 1999). In the Early Pliocene, extensional collapse of the basin, coupled with mud and shale diapirism, influenced sediment deposition (Rodero et al., 1999; Maldonado et al, 1999).

During research cruise TTR-9, three regions of mud volcanism were identified in the Gulf of Cadiz region: the Western Moroccan Field, Middle Moroccan Field and Eastern Moroccan Field (Gardner, 2000; Gardner, 2001). Here, we focus on results from two mud volcanoes (named Yuma and Ginsburg - Gardner, 2000), identified in the Middle Moroccan Field. These were initially identified from $30 \mathrm{kHz}$ sidescan sonar records, and subsequently confirmed from deep-tow camera observations, grab and gravity cores (Gardner, 2000). Single channel seismic data reveal that mud volcanism post-dates sedimentation and is probably Holocene to recent in age (Gardner, 2000). 


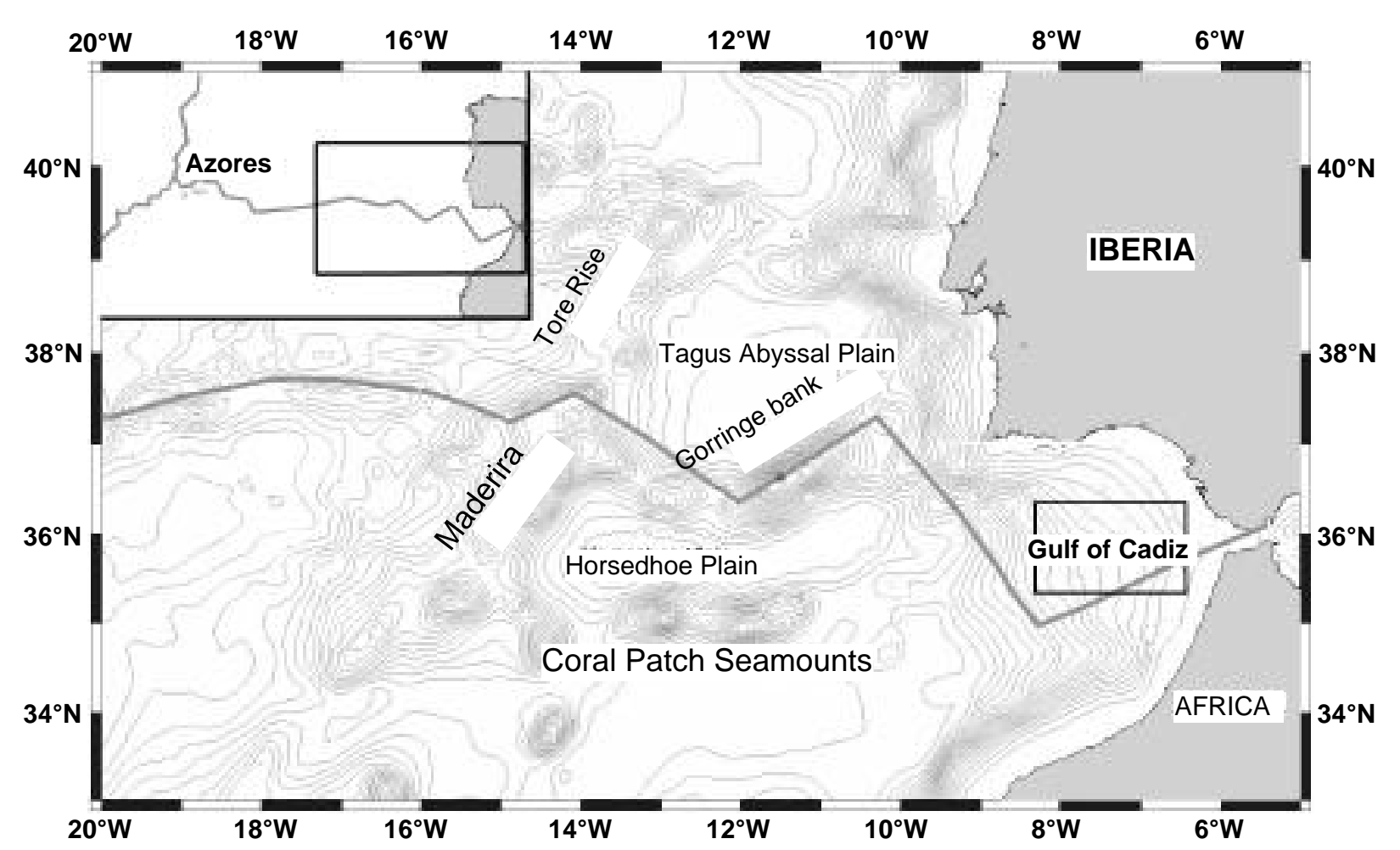

Figure 1 Location map of the study area in the Gulf of Cadiz, eastern North Atlantic.

The two mud volcanoes, Yuma and Ginsburg, lie along an approximately NNW-SSE-oriented line. Their centres are separated by $\sim 7 \mathrm{~km}$, and both volcanoes are roughly $4 \mathrm{~km}$ in diameter with a vertical relief of about $200 \mathrm{~m}$ (Figure $2 \mathrm{a}$ and $\mathrm{b}$ ). The northern-most mud volcano (Yuma) consists of a large, flat-topped dome, upon which is a smaller dome. Both domes have concentric ring structures of high back scatter facies surrounding their centres. Theses ring structures have an amplitude of up to a meter, and comprises circular ridges and troughs. On gravity coring, it was found that the summit of the main dome had a thin layer of pleagic clay and marl (less than $50 \mathrm{~cm}$ thick) overlying a thick sequence of mud breccia, while pelagic sediments were absent from the smaller dome (Gardner, 2000). The southern-most mud volcano (Ginsburg) is of similar proportions to Yuma, but comprises only one conical dome. Like Yuma, the Ginsburg dome is surrounded by concentric rings of ridges and troughs, of a similar wavelength and amplitude. Gravity cores from Ginsburg returned a thin layer of pelagic clay and marl overlying mud breccia at the summit (Gardner, 2000). Both mud volcanoes have convex flank slopes, with Yuma having a flatter top compared with Ginsburg. Thier flanks have similar gradients of about 1:10. Together, Ginsburg and Yuma are located within a moat-like depression, 80-90m deep, that encloses their 
outer margins. The origin of the moat is probably subsidence, resulting from the eruption of mud from some depth below the volcano, and is therefore similar to the processes of caldera formation.

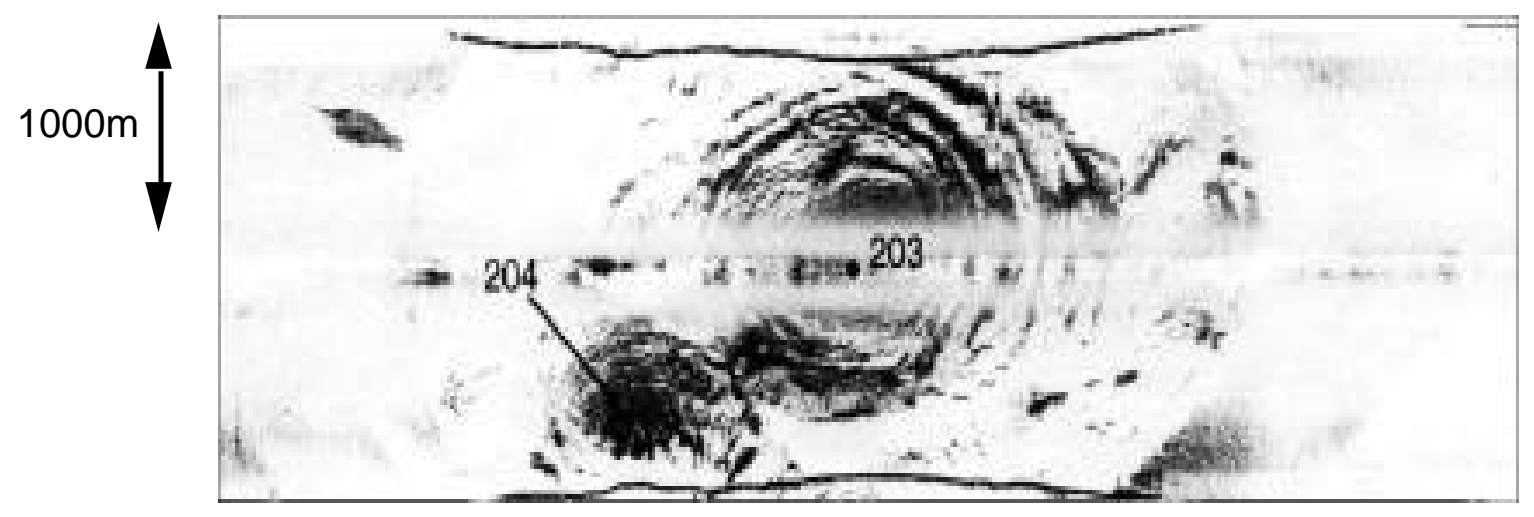

\section{SSE}

NNW

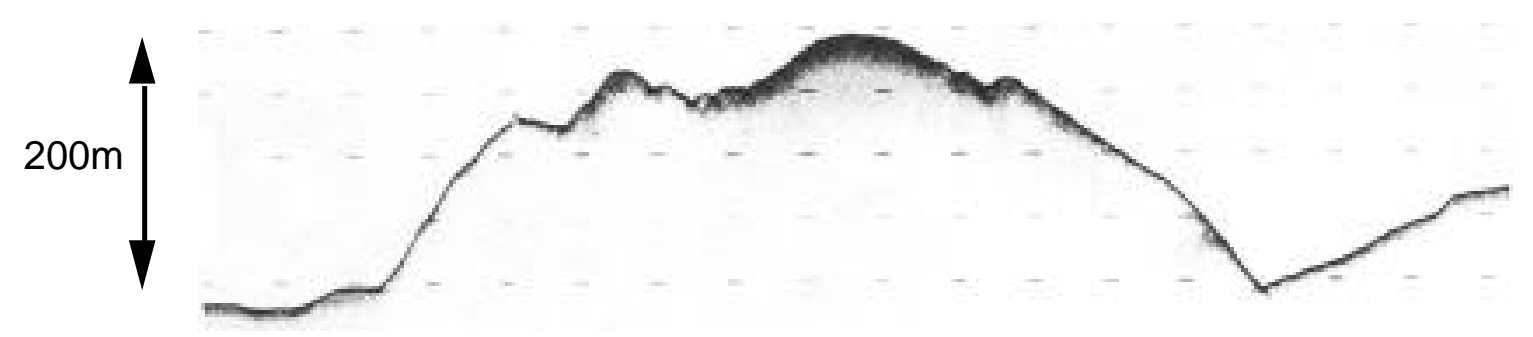

Figure 2a ORE-Tech 30kHz sidescan sonar image (top) and sub-bottom profile (bottom) of the mud volcano Yuma (dark tones indicate high acoustic back-scatter). The core 203 recovered mud breccia with a $\sim 25 \mathrm{~cm}$ cap of pelagic marl and mud while core 204 recovered mud breccia without any pelagic sediment cap (after Gardner, 2001). Note the concentric ring-like structures that are centred on the main summit and the small dome to the left. The profile also shows the summit of the volcano surrounded by a moat, indicating partial subsidence of the top of the main dome. 


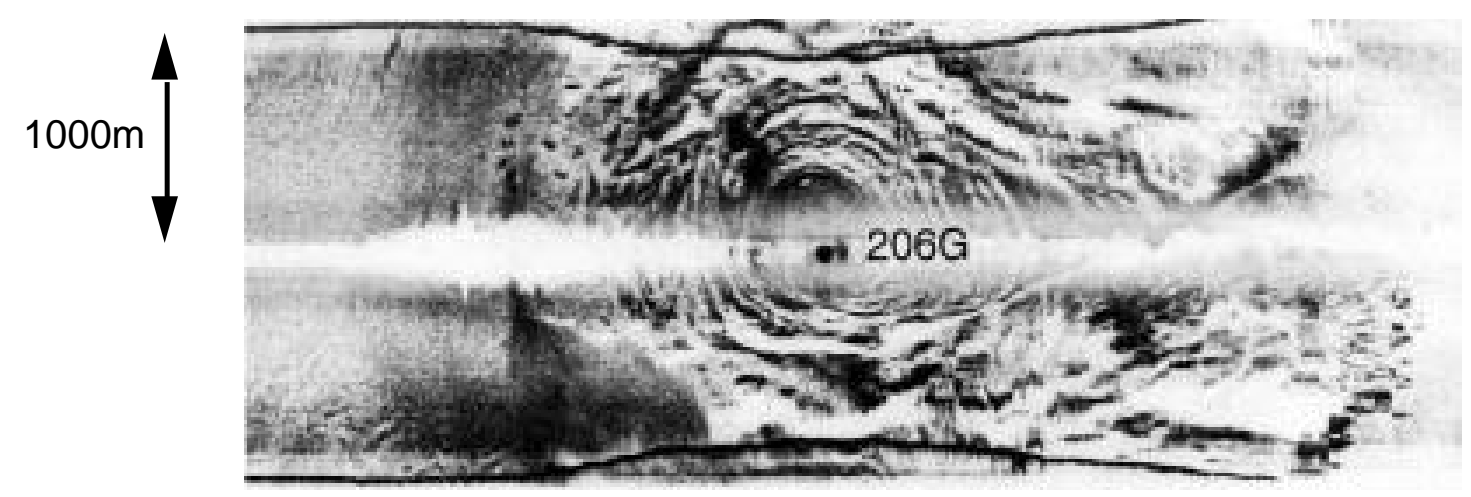

\section{SSE}

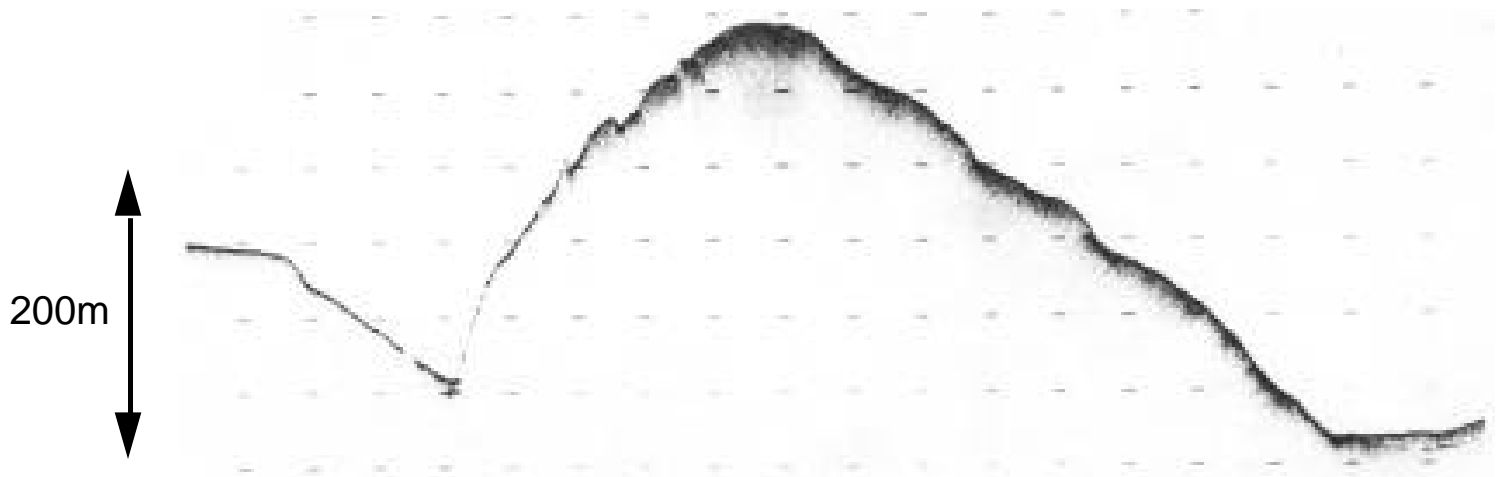

Figure $2 \mathrm{~b} \quad$ ORE-Tech $30 \mathrm{kHz}$ sidescan sonar image (top) and sub-bottom profile (bottom) of the mud volcano Ginsburg. The summit core $206 \mathrm{G}$ recovered mud breccia with a $\sim 50 \mathrm{~cm}$ cap of pelagic marl and mud (after Gardner, 2001). Note, as for Yuma, the concentric ring-like structures that are centred on the main summit of the dome. Also note the elongated flow-like structure on the righthand flank. Unlike Yuma, however, the profile of Ginsburg is more conical indicating there has been little subsidence.

Density measurements made on mud breccia immediately after recovery from the summits of both mud volcanoes yield a range from $2.0 \mathrm{~g} / \mathrm{cc}$ to $1.75 \mathrm{~g} / \mathrm{cc}$. Viscosity measurements were made for mud breccia using a capillary method. This involved forcing a known volume of fresh mud breccia through a tube of known diameter under constant pressure. Different volumes were tested and repeated several times. The tests confirmed a plastic fluid behaviour for the mud breccia, recognised for mud volcanoes elsewhere (Lance et al., 1998), and yielded a wide range of kinematic viscosity $(v)$ of between 0.9 and $3 \mathrm{~m}^{2} \mathrm{~s}^{-1}$. The range of results reflect heterogeneities in the mud breccia, with clastic fragments and variable fluidity. Shear strength measurements, made by Gardner (pers comm.) yield shear strength values of $\sim 5 \mathrm{kPa}$ and $8 \mathrm{kPa}$ for mud breccia recovered from Ginsburg and Yuma, respectively. Although no free gas was evident in the mud breccias, in 
situ gas hydrate crystals were recovered from approximately $1.5 \mathrm{~m}$ below the summit of Yuma (Gardner, 2000). The presence of free gas, variable fluid contents, as well as larger lithclasts (up to several centimetres in diameter) within the mud breccia will alter its effective viscosity. For the purposes of simplifying our modelling, we have treated the mud breccia as homogeneous and assumed an average density of $1.8 \mathrm{~g} / \mathrm{cc}$ and effective kinematic viscosity of $1.5 \mathrm{~m}^{2} \mathrm{~s}^{-1}$. The accuracy of these paramaters is not imperative here, since we are only developing a generic model for the mud volcanoes. Variations in the parameter values may alter the final results, but will not alter the general form of the model. Obviously, to more accurately constrain the evolution of individual volcanoes, these paramaters need to be determined precisely for each system.

\section{Results and Discussion}

\subsection{An isostatic Model}

In the following section we develop a simple buoyancy model to relate the maximum height of a mud volcano to the thickness of its overburden. Such a buoyancy-driven, or isostatic equilibrium, concept is not new and has been applied to igneous volcanic provinces in the past (Vogt, 1974; Cann and Smith, 1993). Its application to mud volcanoes is new, however, and can reveal important information about the depth of the source of the mud breccia within the sediment pile. These estimates allow, among other things, comparison with seismically determined depths to the mud breccia source as well as indications of the stratigraphic depth of origin for lithoclasts contained within the mud breccia (Sadekov and Ovsyannikov, 2000).

All mud volcanoes require that, at some depth within the sediment pile beneath them, they have a reservoir or source of fluidised mud. What drives this mud to the surface is a combination of over pressure, caused to a large extent by the density and weight of the overburden, with possible contributions from mineral dehydartion reactions, as well as biogenic and authogenic gas generation. Assuming over pressure is largely a function of overburden, the maximum height a mud volcano can achieve is a balance between the weight of the over burden and the weight of the mud column from the top of the volcano to the mud reservoir. For mud volcanoes that have achieved their maximum height, we can assume that this reservoir is located at a depth of isostaic 
compensation. For example, the pressure at the base of the column of mud breccia connecting the reservoir to the top of the volcano, plus the overlying seawater, must equal the pressure at the base of the sediment pile plus the overlying seawater (see figure 3 ).

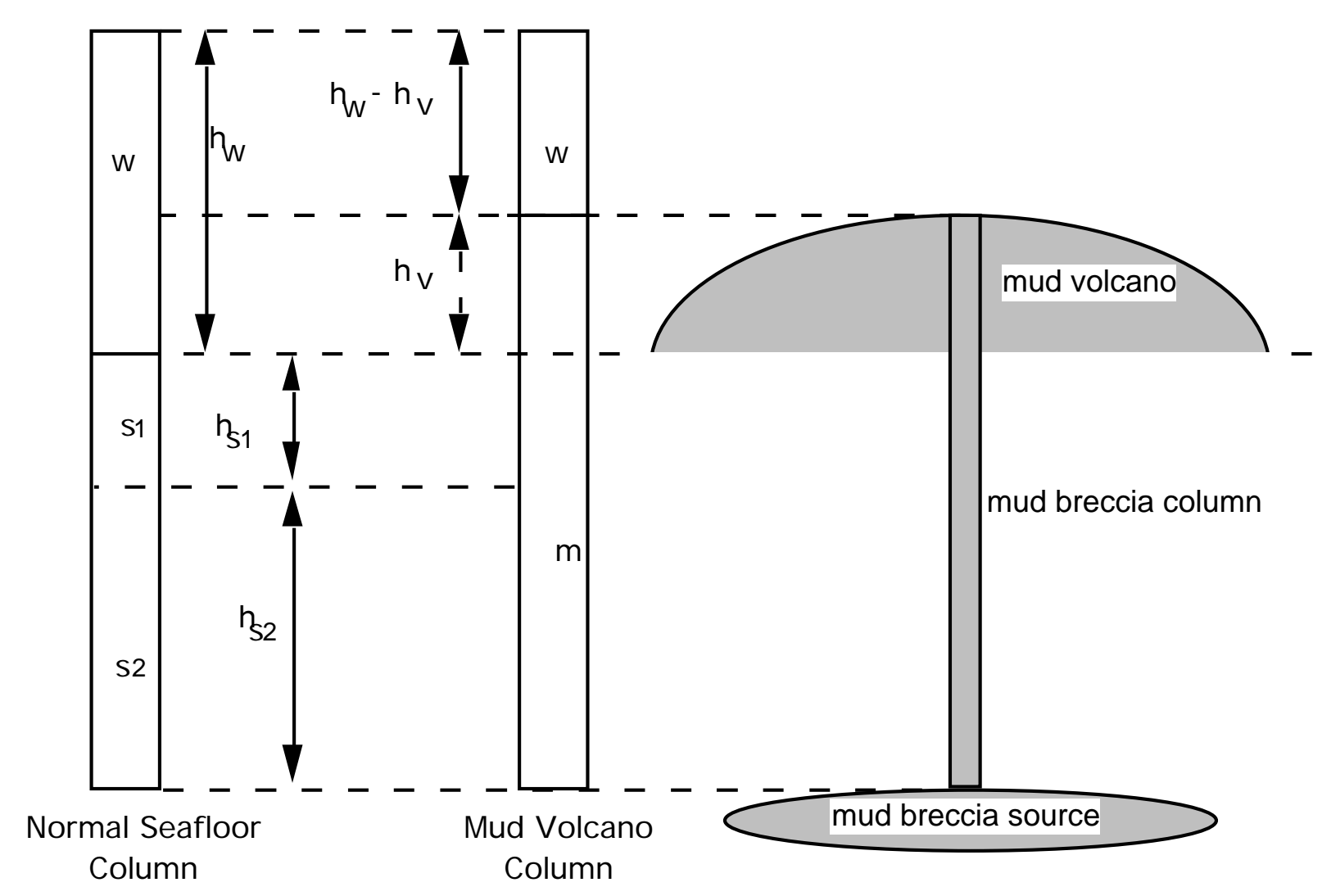

Figure 3 Schematic figure describing the main feature of the isostatic columns of: mud breccia, the mud volcano, and a two-layered sediment column model.

where,

$\rho_{\mathrm{m}}=$ density of mud $\sim 1.8 \times 10^{3} \mathrm{kgm}^{-3}$

$\rho_{\mathrm{W}}=$ density of seawater $\sim 1 \times 10^{3} \mathrm{kgm}^{-3}$

$\rho_{\mathrm{S} 1}=$ density of uppermost sediment $\sim 1.65 \times 10^{3} \mathrm{kgm}^{-3}$

$\rho_{\mathrm{S} 2}=$ density of lowermost sediment $\sim 1.9 \times 10^{3} \mathrm{kgm}^{-3}$

$\mathrm{h}_{\mathrm{S} 1}=$ height of uppermost sediment column (i.e $1 \mathrm{~km}$ )

$\mathrm{h}_{\mathrm{S} 2}=$ height of lower sediment column above depth of isostatic compensation (i.e depth of mud reservoir -

to be determined) 
$\mathrm{h}_{\mathrm{W}}=$ hieght of water column above surrounding seafloor

$\mathrm{h}_{\mathrm{V}}=$ height of volcano above surrounding seafloor $\sim 266 \mathrm{~m}$ (Ginsburg)

A critical parameter in this calculation is the density structure of the sediment pile through which the mud breccia passes. Because no well data are available from the vicinity of Ginsburg and Yuma mud volcanoes, we have used a compilation of sediment density values from accretionary sedmentary sequences, extracted from ODP results (Mascle et al., 1988; Shipley et al., 1995; Karig, 1986; ODP www data source, 2001). The sediment density profile demonstrates an increase in density from $1.3 \mathrm{~g} / \mathrm{cc}$ at the surface to approximately $2 \mathrm{~g} / \mathrm{cc}$ below a depth of $2000 \mathrm{~m}$ subsurface (figure 4). For the purposes of this contribution, we use a simplified two layer sediment density model. For the uppermost $1 \mathrm{~km}$ we use an average density of $1.65 \mathrm{~g} / \mathrm{cc}$ and for sediment deeper than $1 \mathrm{~km}$ we assume an average density of $1.9 \mathrm{~g} / \mathrm{cc}$.

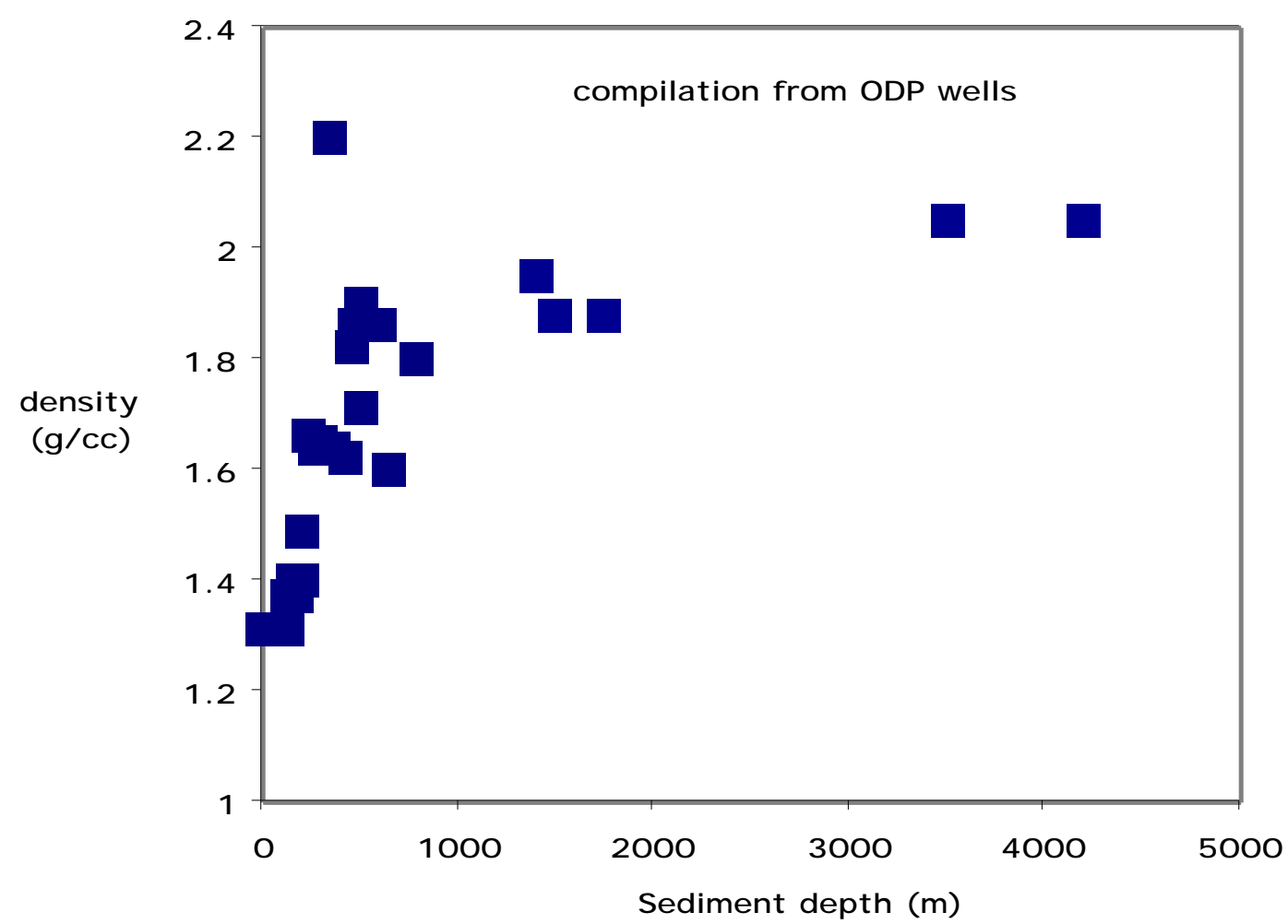

Figure 4 Compilation of clastic sediment density from ODP holes in accretionary complexes including the Barbados Forearc Wedge (see references). The sediment column increases in density from 1.3 to 1.9 over the uppermost $1 \mathrm{~km}$.

Gravity cores from the summits of both Yuma and Ginsburg mud volcanoes, taken during cruises TTR9 and TTR10, found a drape of pelagic sediment overlying the mud breccia (Gardner, 2000). 
This indicates that the summits of the mud volcanoes are no longer active and can be assumed to have reached their maximum height. Therefore, we can derive an expression for the thickness of the sediment column above their mud breccia reservoirs by equating the pressures at the bottom of the sediment column and mud breccia columns.

$$
\begin{array}{lr}
\text { Pressure under normal seafloor column: } & h_{\mathrm{S} 1} \rho_{\mathrm{s} 1}+\mathrm{h}_{\mathrm{s} 2} \rho_{\mathrm{s} 2}+\mathrm{h}_{\mathrm{W}} \rho_{\mathrm{W}} \\
\text { Pressure under mud volcano column: } & \left(\mathrm{h}_{\mathrm{S}}+\mathrm{h}_{\mathrm{V}}\right) \rho_{\mathrm{m}}+\left(\mathrm{h}_{\mathrm{W}}-\mathrm{h}_{\mathrm{V}}\right) \rho_{\mathrm{W}}
\end{array}
$$

Solving for the unknown thickness of the lower sediment column, $\mathrm{h}_{\mathrm{s} 2}$, yields:

$$
h_{s 2}=\left[h v\left(\rho_{m}-\rho_{W}\right)-h_{s 1}\left(\rho_{s 1}-\rho_{m}\right)\right] /\left(\rho_{s 2}-\rho_{m}\right)
$$

Substituting the values for density and volcano height for Yuma (200m) and Ginsburg (266m) into Equation 3, yields a total depth to the mud breccia sources of 4.6 and $4.1 \mathrm{~km}$ respectively. These results are susceptible to variations in the estimates of the density of the sediment column and mud breccia. Increasing the sediment column density, or reducing the mud breccia density, reduces the calculated depth to the mud breccia source. For example, a 10\% error in the average sediment density changes the estimated depth to the mud breccia source by $\sim 30 \%$.

A consequence of the isostatic model is a prediction for the type and location of future eruptions for a mud volcano that has reached its maximum height. Unless the mud volcano subsides, future eruptions can only occur if either the mud breccia density decreases, if there is an increase in its over pressure from causes other than overburden, or if the eruption occurs from the flanks of the volcano. This prediction is supported by observations of the mud volcano Yuma. Its bathymetric profile (figure 2a) shows evidence for subsidence of the main dome's summit. Although cores indicate pelagic drape for this summit, and hence evidence that eruptions have ceased there, the smaller mound on the top of Yuma does not have pelagic drape. We interpret this as evidence for active parasitic cone growth following subsidence, as predicted by our model. The mud volcano Ginsburg does not have any parasitic cones and summit cores show a pelagic sediment veneer. Hence, although it has probably reached its maximum height, unlike Yuma, Ginsburg has not 
experienced summit subsidence and hence there is no reactivation of eruptions. This interpretation is also supported by the fact that Ginsburg is taller than Yuma (by 66m). Assuming both have a similar depth source of fluidised mud, then the model predicts that the lower volcano would be the more active, which it is.

\subsection{An Eruption Model}

In the next section, we attempt to model the processes controlling the eruption, spread and thickness of individual mud breccia flows, and hence understand what ultimately determines the shape of individual mud volcanoes. As already stated, the following modelling is essentially generic. Although we apply it to conical mud volcanoes, and specifically to the two mud volcanoes Yuma and Ginsburg, the form of the model is independent of the input values. The main value of our modelling is to establish the critical parameters that need to be measured from mud volcanoes to understand their physical formation, and to set order-of-magnitude constraints on some of the processes.

\subsubsection{Input parameters}

In order to quantify the flows from mud volcano eruptions, a few basic controlling parameters need to be known. Essential to all calculations involving flows of this type are the physical properties of the fluid, in particular its density and viscosity. Strictly, the viscosity of the mud is a simplification, since it exhibits a plastic fluid behaviour and has a finite shear strength. The finite shear strength is demonstated by the fact that the mud volcanoes form elevated domes. A volcano comprising a purely viscous, Newtonian fluid would continue spreading until its thickness tended towards zero. For the purposes of our modelling, we assume a constant viscosity. Since the shear strength is included in our measurement of the effective viscosity, and it is evident that the mud volcanoes comprise a series of individual units, we assume gravity driven viscous flow to describe the eruption and spread of the mud over the seafloor. The shear strength of the mud breccia only becomes important at the outer boundary conditions of the flow (i.e. when the flow velocity tends towards zero), when gravity induced, viscous stresses within the flow tend towards the value of the shear strength. Similarly, we make no attempt to introduce any component of non-laminar flow 
within the mud eruptions, nor is there any expression for friction between the flow and its base as we consider these make a minor contribution to the total force balance.

\subsubsection{A viscous-gravity current flow: a numerical analogue}

To construct a simple model we can realistically analyse, we consider mud volcanoes to erupt at a constant volume flux, Q, from a point source with a constant conduit diameter, onto a flat, horizontal base. The volume flux, Q, is controlled by the buoyancy of the mud and its kinematic viscosity, $v$. This produces a radially symmetric, laminar flow, whose properties at a given radius and time are uniform. In the case of a 'bottom current', such as that formed by a mud volcano, the erupted material (density $\rho$ ) is denser that the ambient fluid (density $\rho_{a}$, where $\rho>\rho_{a}$ ) and so it flows along the bottom. The flow is driven by this density contrast which is usually expressed in terms of 'reduced gravity', g', where:

$$
\mathrm{g}^{\prime}=\mathrm{g} \Delta \rho / \rho,\left(\Delta \rho=\rho-\rho_{\mathrm{a}}\right)
$$

The flow is retarded by viscous drag (kinematic viscosity, $v$ ) and is retarded by inertia, provided the discharge Froude number is sub-critical, i.e.

$$
\mathrm{U}_{\mathrm{i}} /\left(\mathrm{g}^{\prime} \mathrm{h}_{\mathrm{i}}\right)^{1 / 2}<1
$$

where $U_{i}$ is the horizontal inflow velocity and $h_{i}$ is the depth of the inlet opening (after Didden and Maxworthy, 1982)

For viscous gravity flows, Didden and Maxworthy (1982) describes three main forces, buoyancy, viscosity and inertia, and compare the magnitudes of these at different time (t). For $t<t_{1}$ (see Eqn 6), viscous drag is negligible and inertia is the dominant retarding force.

$$
\mathrm{t}_{1}=\left(\mathrm{Q} / \mathrm{g}^{\prime} \mathrm{v}\right)^{1 / 2}
$$

In order to quantify this initial condition we need to produce an initial estimate of flow rate. The isostatic model, already used to estimate the depth of the mud reservoir, can also be used to predict 
the pressure difference $(\mathrm{P})$ between the top and bottom of the eruptive column for an immature mud volcano. In its initial stage of formation, the volcano is fed by a reservoir or source of mud at depth within the sediment column. At this stage, the volcano has not yet formed any elevated structure at the surface. The pressure difference between the ends of the eruptive column is thus equivalent to the pressure at the base of a column of mud breccia equivalent in height to the depth of the mud source. Using the mud volcano Ginsburg as an example, with an estimated reservoir depth of $4600 \mathrm{~m}$ and a mud density of $1.8 \times 10^{3} \mathrm{kgm}^{-3}$, the resulting pressure difference is $8.1 \times 10^{7} \mathrm{Nm}^{-2}$.

To estimate the flow rate of the mud breccia as it initially erupts, we treat the flow through the volcano conduit (i.e. the open structure linking the summit of the volcano to the fluidised mud source at depth) as forced viscous fluid flow through a capillary (see Equation 7). The driving force is a result of the pressure difference between the top and bottom of the mud breccia column and the retarding forces are viscous drag, friction between non-fluid components of the mud breccia and the conduit wall and tortuosity of the conduit walls. Although our treatment of the eruption rate as capillary flow is obviously simplified, the other effects can not be modelled since there is no evidence for the physical structure of the conduit within and below the mud volcano. Although these variations will ultimately alter resulting values, they have little effect on the general form of the solution. With such an assumption we can apply equation 6 to describe the flow rate:

$$
\mathrm{Q}=\mathrm{P} \pi \mathrm{r}^{4} / 81 \eta
$$

Where: $\mathrm{P}$ is the driving pressure, 1 is the length of the conduit (in this case the height of the initial mud breccia column), $r$ is the average radius of the conduit, and $\eta$ is the dynamic viscosity of the mud breccia.

Using the mud volcano Ginsburg as an example, we take the initial height of the eruptive column, 1 , to be $4600 \mathrm{~m}$ (derived from our isostatic model) and the dynamic viscosity, $\eta$, to be $3000 \mathrm{kgm}^{-1}$ (measured from the mud breccia). Although none of the data for Ginsburg give a clear indication of the radius of the conduit, its bathymetric profile shows an approximately flat top with a radius of $100 \mathrm{~m}$, providing us with a maximum dimension. To cover a range of possibilities, we calculate the flow rate, $\mathrm{Q}$, (from Equation 7) and the duration of the inertia-dominated flow, $\mathrm{t}_{1}$ (from Equation 6), for conduit radii across several orders of magnitude; e.g. 


$$
\begin{array}{ll}
\text { If } \mathrm{r}=100 \mathrm{~m}, \mathrm{Q}=2.3 \times 10^{7} \mathrm{~m}^{3} \mathrm{~s}^{-1}, & \mathrm{t}_{1}=2820 \mathrm{~s}=\sim 1 \mathrm{hrs} \\
\text { If } \mathrm{r}=10 \mathrm{~m}, Q=2.3 \times 10^{3} \mathrm{~m}^{3} \mathrm{~s}^{-1} & \mathrm{t}_{1}=28 \mathrm{~s} \\
\text { If } \mathrm{r}=1 \mathrm{~m}, \quad \mathrm{Q}=0.23 \mathrm{~m}^{3} \mathrm{~s}^{-1}, & \mathrm{t}_{1}=0.3 \mathrm{~s}
\end{array}
$$

The sidescan sonar record for both Yuma and Ginsburg show that each volcano is at least $2 \mathrm{~km}$ in diameter. Cores from the flanks of the volcanoes show individual mud flows of up to $0.5 \mathrm{~m}$ thick (Gardner, 2000). It is unlikely that individual viscous flows will take less than a few tens of minutes to reach the margin of the volcano, and more likely that they take up to several tens of hours or even days. As an initial condition, if we assume individual eruption duration is a matter of tens of hours or days, and the conduit radius anything up to a few tens of metres, then the length of the initial period of inertia dominated flow is negligible in comparison. For the time being, therefore, if we assume that the conduit radius is of the order of several tens of metres radius, we can ignore the initial period of inertially retarded flow behaviour. In the following sections, we will gain a better estimate the volume flux, allowing us to return to this point; first to prove that $\mathrm{t} 1$ is indeed negligible and second to improve our estimate of the conduit radius. Also, although the effects of inertial retarding forces will change the details of the flow only during the initial brief period, it will not significantly change the overall phenomena described here.

For $\mathrm{t}>\mathrm{t}_{1}$, the dominant retarding force is the viscous drag force. In this regime, Didden and Maxworthy (1982) calculate the height at the eruptive centre, ho, and the radius of the flow, $\mathrm{R}$, to be described by the following two expressions:

$$
\begin{aligned}
& \mathrm{R} \sim\left(\mathrm{g}^{\prime} \mathrm{Q}^{3 / v}\right)^{1 / 8_{\mathrm{t}} 1 / 2} \\
& \mathrm{~h}_{0} \sim\left(\mathrm{vQ} / \mathrm{g}^{\prime}\right)^{1 / 4}
\end{aligned}
$$

(The symbol $\sim$ denotes accuracy is only to the nearest order of magnitude) 
Furthermore, by differentiating the radius with respect to time, and assuming a constant flow rate, an expression for the velocity of the flow front, $\mathrm{U}$, can be found:

$$
\mathrm{U} \sim\left(\mathrm{g}^{\prime} \mathrm{Q}^{3 / \mathrm{v}}\right)^{1 / 8_{\mathrm{t}}-1 / 2}
$$

\section{Estimation of Flow Rate}

As a first approximation we consider the mud volcanoes to have been erupted as single events. Using our measurements of volcano height, radius, viscosity and density (derived for mud breccia from Yuma and Ginsburg), equation (9) predicts that an individual flow ( $\mathrm{h}_{0}$ ) of approximately $200 \mathrm{~m}$ height would require a flow rate of about $5 \times 10^{9} \mathrm{~m}^{3} \mathrm{~s}^{-1}$ to form. Equation (8) then predicts an eruption duration of only $0.1 \mathrm{~s}$. These figures are obviously unrealistic and lead us to the conclusion that the structure must be composed of a series of superimposed, discrete flows.

Equation (9) shows that the central height of an individual mud flow is independent of time. With constant volume flux, the velocity of the flow front will decrease maintaining a constant flow thickness. From this we make the assumption that the thickness of a flow, at any given radius, is independent of time and equal to the height of the flow at its centre. The product of such a model is a roughly cylindrical flow that spreads radially outwards from its central source or out flow point. Subsequent eruptions will be superimposed upon preceding ones, building a layered mud volcano structure.

During construction of mud volcanoes, the eruption of subsequent flows will add to the height of a volcano. This will reduce the isostatic disequilibrium driving each new eruption, which in turn will reduce the volume flux $(\mathrm{Q})$ causing the new flow to be both thinner and spread more slowly (from equations 8 and 9) than its predecessor. Therefore, our model predicts an idealised structure for a conical mud volcano, like Ginsburg, as one composed of multiple, laminar flows, stacked vertically and each decreasing in thickness and radius with height (figure 5). Because the surface of each flow 
is horizontal, subsequent new flows are extruded in an identical way to their predecessors. If the duration of the new flow is long enough (i.e. significantly longer than the previous flow), then it will reach the edge of the underlying flow and cascade down the flank of the volcano. For constant eruption conditions and roughly similar eruption duration, our model predicts decreasing flow thickness and radius with increasing volcano height (figure 6). The result of such geometry is a dome-like structure, similar to the profiles observed for the Yuma and Ginsburg mud volcanoes (figure 7).

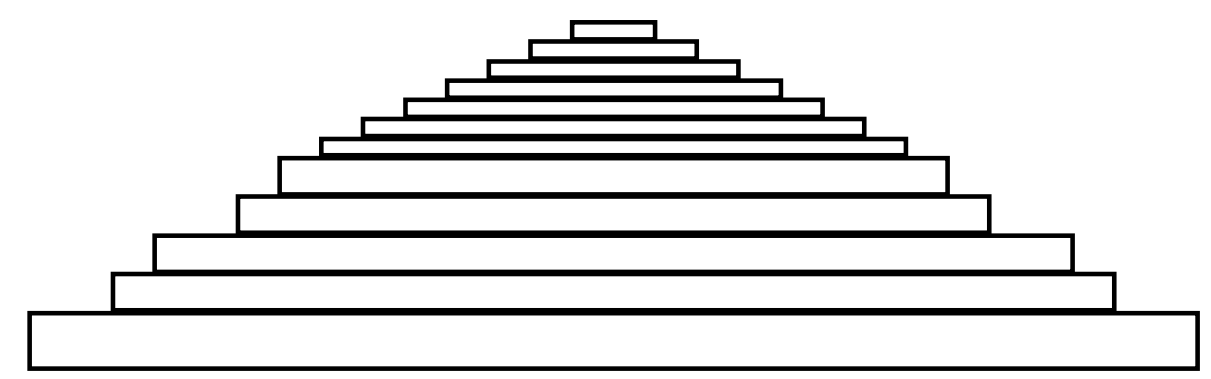

Figure 5 Schematic cross-section (not to scale) showing elements of a vertically stacked model of mud volcano formation in which the thickness and radius of superimposed, cylindrical mud flows decrease with increasing volcano height. 


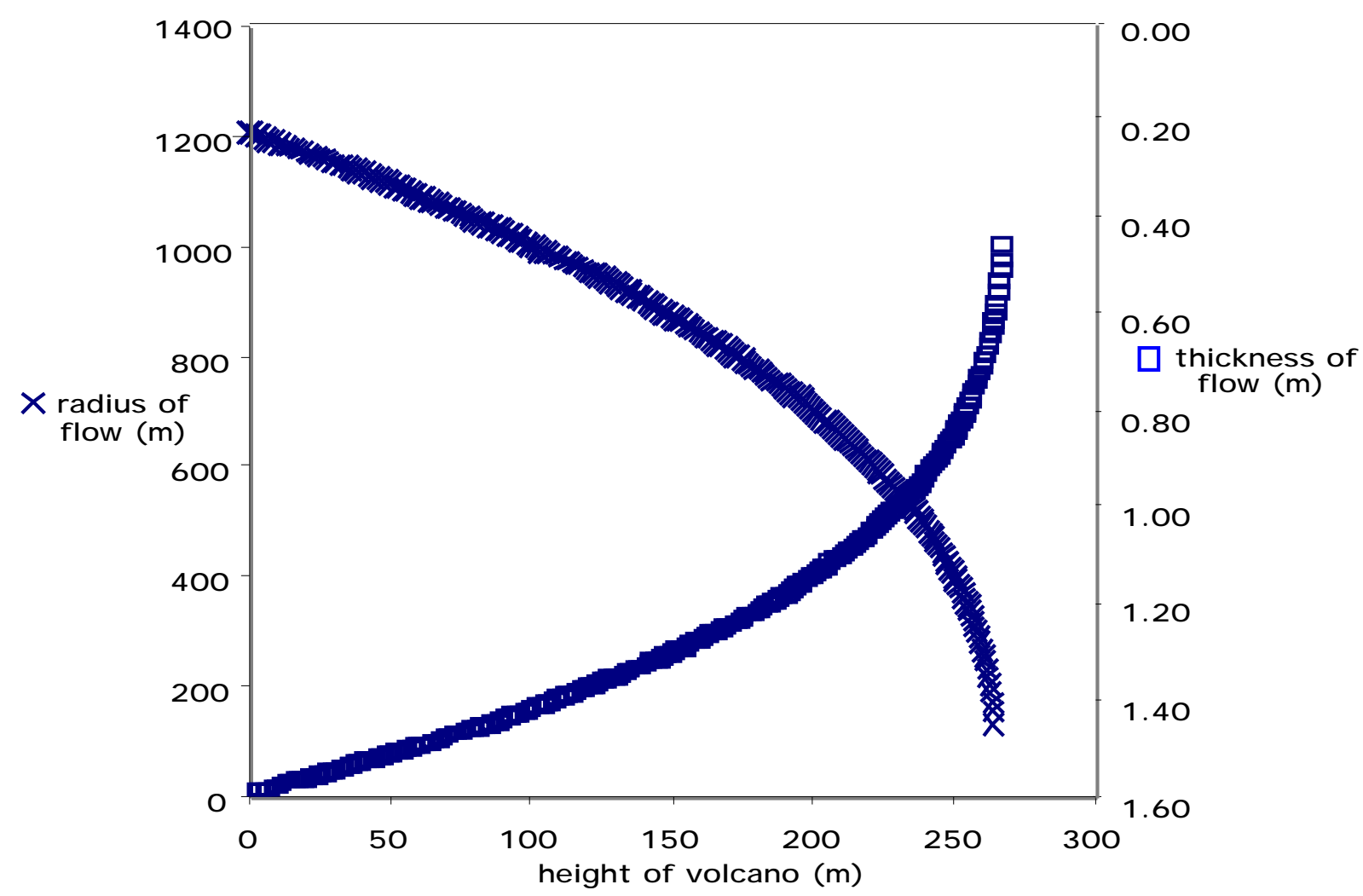

Figure 6 Results of modelling individual mud flow thickness and radius with height of the volcano, using the isostatic equilibrium model to derive the driving force for eruption and a viscous gravity current flow model for each mud flow. The flow thickness decreases because, as the volcano height increases, the driving force decreases resulting in a lower volume flux for the erupted mud breccia. Similarly, the flow radius decreases, as the volcano height increases, as a result of a lower volume flux and hence lower spreading rate for the erupted mud breccia. 


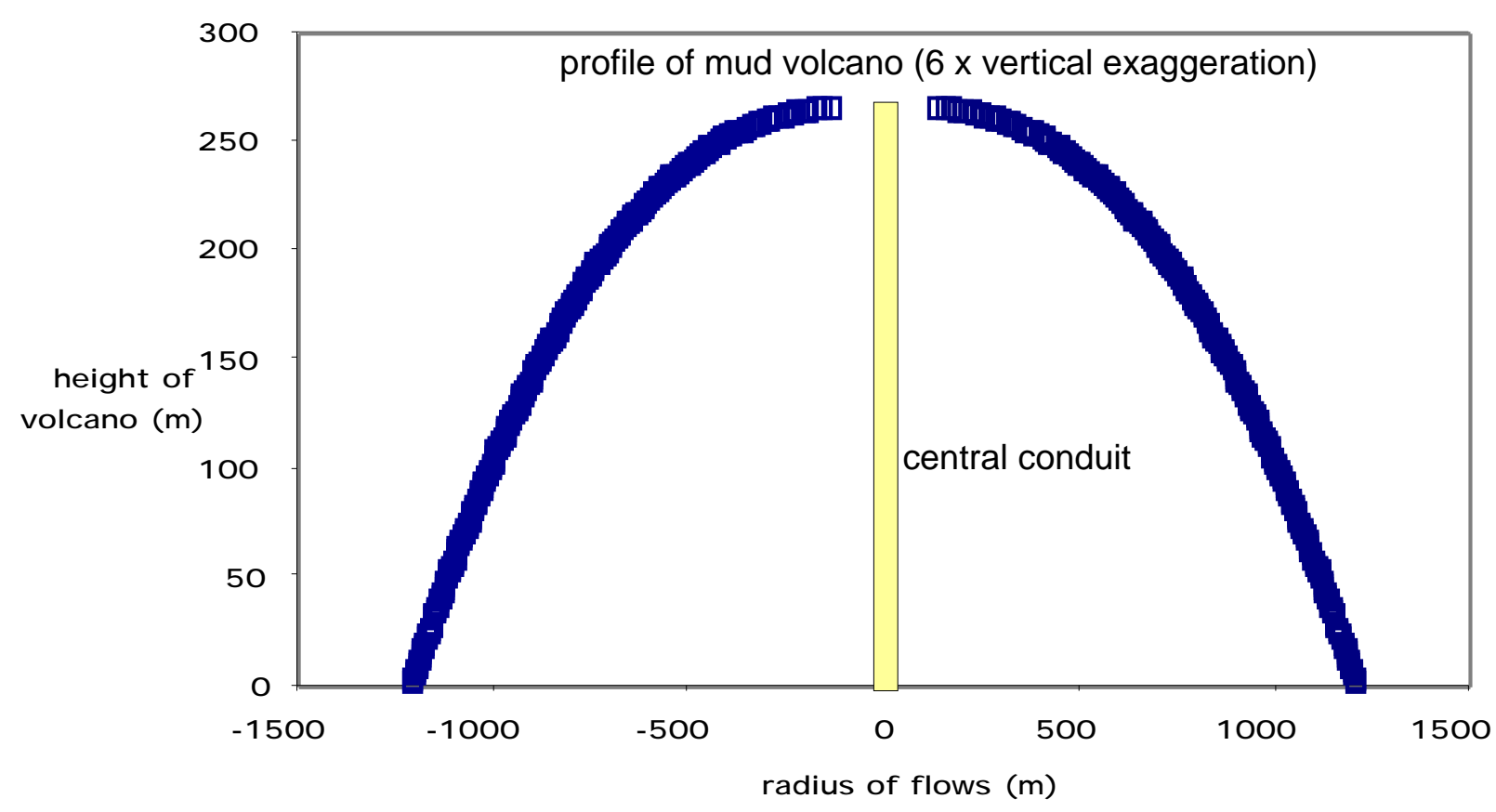

Figure 7 Results of modelling superimposed mud flows of decreasing radii and thickness with height, using the same paramaters as for figure 6 . The result of the accumulated flows is a convex outwards shaped dome with a flat-top and increasingly steep sides. This shape roughly matches that shown by the profiles of the conical mud volcanoes Ginsburg and Yuma (Figure 2). Although this profile is modelled for starting conditions derived for Yuma and Ginsburg, the general shape of the profiles is generic and simply a function of the form of the model.

\section{Estimation of Flow Thickness}

Many $100 \mathrm{kHz}$ OREtech side-scan sonar images show closely spaced concentric rings about the centre of the mud volcanoes. Gardner (2000) interprets these structures as subsidence features. However, we observe the concentric rings for both Yuma (which has arguably experienced some component of summit subsidence) as well as Ginsburg (for which there is no evidence from the bathymetric profile for summit collapse). Therefore, we suggest alternative mechanisms for the formation of these structures, at least on the two mud volcanoes in question. Similar, although smaller-scale, structures are observed in magmatic lavas (the pahoehoe texture of ropy sheet flows). However, the work of Fink and Griffith identifies these as folds formed by the deformation of a 
solidifying crust. Obivously this is not applicable to submarine mud volcanoes since there is no cooling effect of the mud breccia, which is erupted as a fluid at near the ambient temperature of the seafloor, and no phase transition akin to the solidification during cooling of magmatic lava occurs. An alternative explanation for the origin of the rings is a periodic fluctuation in flow rate during the formation of the mud volcano as a single eruption event. However, our analysis has already ruledout a single eruption model for the formation of these volcanoes, requiring an alternative explanation.

Instead, we propose that each ring represents an individual, near-circular, mud flow front. In this case, our model predicts the lowermost flows are those which have the greatest radius and are hence the oldest. Furthermore, these outermost rings are more likely to be partially obscured by pelagic sediment drape and the effects of viscous slumping than the younger, innermost rings. These predictions are supported by side-scan sonar images of the ring structures which show the rings toward the centre are very sharply defined (i.e. with less slumping and drape), while the outer rings appear smoother (i.e. partially buried by pelagic sediment and slumped flow fronts). Our model does not preclude the over-spill of flows down the volcano flanks. Such over-spill is quite feasible should the duration of an individual flow allow its front to expand beyond the limit of its predecessor. However, such over-spills will have a different appearance on side-scan sonar records, forming down-flank oriented tongues of mud breccia. Although an example of this is evident on the NW flank of Ginsburg volcano (figure 2), their occurrence is rare on the two conical volcanoes in question.

For the mud volcano Ginsburg, seven clearly identifiable rings were counted with radii of between $480 \mathrm{~m}$ and $580 \mathrm{~m}$ and at heights on the flanks of the volcano of between $125 \mathrm{~m}$ and $219 \mathrm{~m}$ (i.e. spanning a height range of $94 \mathrm{~m}$ ). This gives an average individual flow thickness of $1.3 \mathrm{~m}$. For this value, equation (9) yields a volume flux estimate (Q) of $10 \mathrm{~m}^{3} \mathrm{~s}^{-1}$. In turn, this is substituted into 
equation (8) to give an estimated mud flow eruption duration of $12 \mathrm{hrs}$ (i.e. to reach the average radius for these flows of 530m). For the mud volcano, Yuma, six rings we visible between $420 \mathrm{~m}$ and $515 \mathrm{~m}$ in radius spanning a height of $94 \mathrm{~m}$ again. This averages to an individual flow thickness of $1.6 \mathrm{~m}$, which when substituted into equation (9) yields a flow rate of $20 \mathrm{~m}^{3} \mathrm{~s}^{-1}$. From equation (8), about 5 hrs would be required to reach the average radius for these flows of $470 \mathrm{~m}$. The most recent flows at the summit of the Yuma and Ginsburg volcanoes are indicated from gravity cores (e.g. cores AT-203G, AT-204G, AT-206G and AT-213G) to rarely exceed 0.5m thick (Akhmanov et al., 2000). However, using the constriants provded by the height, radius and mud breccia density for the volcanoes Yuma and Ginsburg, our model predicts that flow thickness at the summit should be about $0.4 \mathrm{~m}$ (e.g. refer to figure 6), which is similar to those observed by Akhmanov et al., (2000).

$\underline{\text { Revised Estimate for Inertially-dominated Flow, Conduit Radius and Calculated Exit Velocity }}$

Our calculated estimates for mud breccia flow rate can now be used to re-assess our preliminary value of $\mathrm{t}_{1}$, the duration of the initial, inertially-dominated flow regime. We have estimates of flow rates of between 10 and $20 \mathrm{~m}^{3} \mathrm{~s}^{-1}$ which, when substituted into equation (5), give values of $\mathrm{t} 1$ as $1.2 \mathrm{~s}$ and $2.7 \mathrm{~s}$ respectively. In comparison with our calculated total flow duration of between 5 and $12 \mathrm{hrs}, \mathrm{t} 1$ is negligible hence justifying our initial assumption.

The data from the mud volcano, Ginsburg, indicates a flow rate of $10 \mathrm{~m}^{3} \mathrm{~s}^{-1}$ at a height of $172 \mathrm{~m}$ above the surrounding sea-floor (i.e. height at which the mud flow was erupted) and a mud column height of $4272 \mathrm{~m}$ (i.e. $4100 \mathrm{~m}=$ depth to mud source, plus $172 \mathrm{~m}=$ height of volcano for calculated mud flow). Using $\mathrm{P}=\rho \mathrm{gh}$ with $\rho=1.8 \times 10^{3} \mathrm{kgm}^{-3}$, a pressure difference of $7.710^{7} \mathrm{Nm}^{-2}$ is created between the reservoir and the surface. Substituting these values into equation (7) for the 
flow rate, $\mathrm{Q}$, gives a conduit radius of only $1.4 \mathrm{~m}$. Note that equation (7), when solved for the radius of the conduit, yields a result that is dependant only on the $1 / 4$ power of the products of viscosity, conduit length, volume flux, and driving pressure, and therefore is relatively insensitive to the values of these parameters. Since the volume flux, $\mathrm{Q}$, and exit velocity, $\mathrm{v}_{\mathrm{e}}$, are linked only by the conduit area, A, we can use these figures to determine the vertical velocity of the mud breccia as it exits the top of the conduit.

$$
\begin{aligned}
& \mathrm{Q}=\mathrm{v}_{\mathrm{e}} \mathrm{A} \\
& \mathrm{v}_{\mathrm{e}}=\mathrm{Q} / \pi \mathrm{r}^{2}
\end{aligned}
$$

Using a calculated volume flux (Q) of $10 \mathrm{~m}^{3} \mathrm{~s}^{-1}$, and a conduit radius (r) of $1.4 \mathrm{~m}$, yields a value for the vertical ascent rate and exit velocity $\left(\mathrm{v}_{\mathrm{e}}\right)$ of mud breccia at the top of the volcano of $1.6 \mathrm{~ms}^{-1}$. For the volcano Ginsburg, we calculate that, to achieve its observed height of $266 \mathrm{~m}$, requires at least 234 flows ranging in thickness from $\sim 1.6 \mathrm{~m}$ (near the base) to $\sim 0.4 \mathrm{~m}$ (at the summit). Disregarding periods of inactivity, we calculate a total duration of eruption (i.e. constant for each flow, but with an undefined hiatus between flows) of about 117 days.

\section{Conclusions}

The phenomena of mud volcanoes is common in ocean settings globally. Although a variety of processes is probably involved in their formation, we can reduce the physical processes to a number of dominant ones that describe the maximum height that a mud volcano can build, the thickness and radii of individual flows, and the duration and volume flux for each erupted mud flow. Together, these processes are responsible for the first-order shape of the mud volcano. We have developed a model for the formation of conical-shaped mud volcanoes, based on buoyancy-driven, viscously-retarted eruptions. Although a simplification, our modelling of the primary physical 
processes allows us to predict the depth to the mud sources as well as determine the flux of material erupted from within the sediment column. Minimum age constraints can be placed on the duration of mud flow eruptions and hence on the volcano itself. More importantly, modelling allows an understanding of the key parameters that control mud volcano evolution. Where different morphologies are encountered, whether they are in the same mud volcano or between different volcanoes, the models indicate what physical conditions are dominant in causing these changes.

Results from the modelling, applied to conical-shaped mud volcanoes in the Gulf of Cadiz, predict an evolution in which the outermost flows are the oldest and thickest, and successively higher, flows are younger, thinner and have smaller radii than those below. Individual flows, located half way up the flanks of the mud volcanoes, Ginsburg and Yuma, are found to be between $1.3 \mathrm{~m}$ and 1.6m. Using a model for viscous gravity flows (Didden and Maxworthy, 1982), flow rates are calculated to be between 10 and $20 \mathrm{~m}^{3} \mathrm{~s}^{-1}$ requiring up to $12 \mathrm{hrs}$ duration and a conduit radius of about $1.4 \mathrm{~m}$, giving an vertical exit velocity of $1.6 \mathrm{~ms}^{-1}$. Based on our model, we predict that these mud volcanoes comprises about 234 individual erupted over a minimum, cumulative period of activity of 117 days.

\section{Acknowledgements}

We are indebted to Michael Ivanov, Neil Kenyon, Joan Gardner and José Monteiro for helpful discussions concerning the nature of submarine mud volcanism and on specific aspects of this work, as well as access to the data. Also to the officers and crew of the R/V Professor Logachev without whom none of the data discussed here would be available. During this work, J. Biggs was supported by a Southampton Oceanography Centre, Summer School scholarship. B. Murton is supported by a Natural Environment Research Council core-strategic science programme, within the Crustal Processes Group at Southampton Oceanography Centre. 


\section{References Cited}

Akhmanov, G., Akhmetzhanov, A., Stadnitskaya, A., Kozlova, E., Mazurenka, L., Teixeira, F., Sautkin, A., Dixon, D., Ovsyannikov, D., Sadekov, A., Rasul, N., Belenkaya, I., Volakova, Yu., Suslova, E. and Goncharov, D. Mud diapirism and mud volcananism study: gulf of Cadiz/Morroccan margin. In: Kenyon, N. H., Ivanov, M. K., Akhmetzhanov, A. M. and Akhmanov, G. C., (eds), 2000. Multidisciplinary Study of the Geological Processes on the North East Atlantic and Western Mediterranean Margins. IOC Technical Series 56, UNESCO, 101pp plus figures.

Blankenship, C. L., 1992, Structure and palaogeography of the External betic Cordillera, southern Spain. Marine and Petroleum Geology, 9, 256-264.

Cronin, B. T., Ivanov, M. K., Limonov, A. F., Egorov, A., Akhmanov, G. G., Akhmetjanov, A. M., Kozlova, E., 1997. New discoveries of mud volcanoes on the eastern Mediterranean Ridge, Journal of the Geological Society,London, 154: 173-182.

Dewey, J. F., Helman, M. L., Turco, E., Hutton, D. H. W. and Knott, S. D. 1989. Kinematics of the Western Mediterranean. In: Coward, M. (ed), Alpine Tectonis. Special Publication of the Geological Society, London. 45, 265-283.

Didden N., Maxworthy T., 1982. The viscous spreading of plane and axisymmetric gravity currents. Journal of Fluid Mechanics, 121, 27-42.

Flynch, J. A., Bally A. W. and Wu, S., 1996. Emplacement of a passive-margin evaporitic alochthon in the Betic Cordillera of Spain. Geology, 24, 1, 67-70.

Gardner, J., 2000. Gulf of Cadiz/Moroccan margin, a mud diapirism and mud volcanism study. In: Kenyon, N. H., Ivanov, M. K., Akhmetzhanov, A. M. and Akhmanov, G. C., (eds), 2000. Multidisciplinary Study of the Geological Processes on the North East Atlantic and Western Mediterranean Margins. IOC Technical Series 56, UNESCO, 101pp plus figures.

Gardner, J. M., 2001. Mud volcanoes revealed and sampled on the Western Moroccan continental margin. Geophysical Research Letters, 28, 339-342.

Hovland, M., Hill, A., Stokes D., 1997. The structure and geomorphology of the Dashgil mud volcano, Azerbaijan, Geomorphology, 21: (1) 1-15.

Karig, D.E., 1986. Physical properties and mechanical state of accreted sediments in the Nankai Trough, S. W. Japan. In: Moore, J.C. (Ed.), Structural Fabrics in Deep Sea Drilling Project Cores from Forearcs,. Mem. Geol. Soc. of Am., 66:117-133. 
Kenyon, N. H., Ivanov, M. K., Akhmetzhanov, A. M. and Akhmanov, G. C., (eds) 2000. Multidisciplinary Study of the Geological Processes on the North East Atlantic and Western Mediterranean Margins. IOC Technical Series 56, UNESCO, 101pp plus figures.

Lance, S., Henry, P., Le Pichon, X., Lallemant, S., Chamley, H., Rostek, F., Faugeres, J. C., Gonthier, E,, Olu. K., 1998. Submersible study of mud volcanoes seaward of the Barbados accretionary wedge: sedimentology, structure and rheology, Marine Geology, 145, 255292.

Limonov, A. F., vanWeering, T. C. E., Kenyon, N. H., Ivanov, M. K. , Meisner, L. B., 1997. Seabed morphology and gas venting in the Black Sea mud volcano area: Observations with the MAK-1 deep-tow sidescan sonar and bottom profiler, Marine Geology, 137, 121136.

Maldonado, A. and Comas, M. C., 1992. Geology and geophysics of the Alboran Sea: An introduction. Geo-Marine Letters, 12, 61-651992

Maldonado, A., Somoza, L. and Pallarés, L., 1999. The Betic orogen and the Iberian-African plate boundary in the Gulf of Cadiz; geological evolution (central North Atlantic), Marine Geology, 155, 9-43.

Maldonado, A., Somoza, L., 1997. Al zona de fractura Azores-Gibraltay las cadenas beticas en el Golfo de Cadiz. Evolucion Geologica. Abstract: $2^{\text {nd }}$ Congress Margen continental Iberico Atlantico. University Cadiz, 71-72.

Mascle, A., Moore, J.C., Taylor, E., et al., 1988. Proc. ODP, Init. Repts., 110: College Station, TX, (Ocean Drilling Program).

Milkov, A. V., 2000. Worldwide distribution of submarine mud volcanoes and associated gas hydrates, Marine Geology, 167, 29-42.

Rodero, J., Pallerés, L., and Maldonado, A., 1999. Late Quaternary seismic facies of the Gulf of Cadiz Spanish continental Margin: depositional processes influenced by sealevel changes and tectonic controls. Marine Geology, 155, 13-56.

Sadekov, A. Y. and Ovsyannikov, D. O., 2000. Age of rock clasts from the Yuma and mud volcano bressia on the basis of foraminiferal study (Gulf of Cadiz, NE Atlantic). In: Geological processes on European continental margins (TTR-9 Post-Cruise Conference). Abstracts, University of Granada. 
Shipley, T., Ogawa, Y., Blum, P., et al., 1995. Proc. ODP, Init. Repts., 156: (Ocean Drilling Program), College Station, TX, (Ocean Drilling Program).

Smith, D. K., Cann, J. R., 1993. Building the crust at the Mid-Atlantic Ridge, Nature, 365, 707715.

Srivastava, S. P., Schouten, H., Roest, W. R., Klitgord, K. D., kovacs, L. C., Veroef, J. and Macnab, R,. 1990. Iberian plate kinematics; a jumping plate boundary between Eurasia and Africa. Nature, 344, 756-759.

Vogt, P. R., 1974. Volcano height and plate tectonics, Earth and Planetary Science Letters, 23, 337348.

Wilson, R. C. L., Hiscott, R. N., Willis, M. G. and Gradstein E. M., 1989. The Lusitanian basin of West-Central Portugal: Mesozoic and Tertiary tectonic, stratigraphic, and subsidence history. In: Tanard, A. J., Balkwill, H. R., (eds), Extensional tectonics and stratigraphy of the North Atlantic margins. AAPG Memoir 46, 341-361.

WWW-data sources; http://www. ldeo.columbia.edu/BRG/ODP/DATABASE 